\title{
THE ROLE OF BOARD STRUCTURE IN PREDICTING FINANCIAL DISTRESS IN MALAYSIA
}

\author{
ROHANI MD RUS \\ School of Economics, Finance and Banking \\ UUM College of Business \\ Universiti Utara Malaysia
}

\begin{abstract}
The aim of this study was to examine the impact of board characteristics on financial distress in companies. Specifically this study examined board attributes (size of board, percentage of inside directors, CEO as founder, CEO as chairman and CEO duality) and its relation with companies that experienced financial distress after controlling for leverage, market return, lagged of market return and GDP growth. Compared with previous studies in Malaysia, this study used of the PN17 criterion to select the sample and that defined the shareholder's equity was less than $25 \%$ of issued and paidup capital of a firm. Using data from 2004 to 2009, the results showed that size and CEO-founder were negatively significantly related to distress while CEO duality and fraction of independent director affected distress positively. This study could be used to measure the effectiveness of The Malaysian Code on Corporate Governance (MCCG). This study is also useful to directors, investors and authorities who would want to know which corporate governance factors explain distress.
\end{abstract}

Keywords: Financial distress, Corporate governance, Board structure, Malaysian Code of Corporate Governance.

Received: 8/5/2017

Revised: 15/2/2018

Accepted: 28/2/2018

\section{Introduction}

In recent years, the number of high-profile scandals involving abuse of corporate power and alleged criminal activity by corporate officers has risen and as a result, the issue of corporate governance has received 
increased attention. The abuse of corporate power comes about as a result of a company not adhering to good corporate governance. Normally, companies with bad corporate governance are the ones that will be in trouble, and hence be forced into bankruptcy. Seeing the importance of corporate governance, the government of Malaysia introduced the Malaysian Code on Corporate Governance (MCCG) in the year 2000 which provides principles that companies must adhere to while running their operations. In essence, it refers to the rules, processes or laws by which businesses are operated, regulated and controlled. This is in line with Wruck (1990) who found that corporate governance factor is one of the factors that leads the company into distress. Taking this into consideration, this study examined the board structures of companies and their relationship with financial distress.

Recent studies have shown the importance of board structure in explaining the success or decline of a company (Md-Rus et al., 2013; Daily, Dalton, \& Canella, 2003). One of the most important characteristics of board structure is its independence. Securities Commission of Malaysia has highlighted the importance of board independence and made it as its first principle in all of its corporate governance code; Malaysian Code on Corporate Governance 2000 (MCCG, 2000) with revisions in 2007 and 2012. It is expected that a blend between independent and non-independent directors would provide a check and balance mechanism in monitoring managerial actions. However, there is inconclusive evidence to support the association of director independence in explaining financial distress. For example, Daily and Dalton (1994) showed that bankrupt firms were characterized by a greater number of independent directors while Abdullah (2006) found that independent directors are not significant in explaining a company's distress condition. Elloumi and Gueyie (2001) and Platt and Platt (2012) support the idea that the presence of independent directors is positively related to companies' financial health as they are more willing to use their power to monitor and discipline the managers. Likewise, there is inconclusive evidence to support that board size affects performance (Fama \& Jensen, 1989; Chaganti et al., 1985; Platt \& Platt, 2012). A larger board size leads to a greater pooling of experience and expertise and should lead to better performance. However, a smaller board leads to faster decisionmaking. In distressed firms, faster decision-making is very important. Hence it is important to study whether in the Malaysian context, board size and percentage of independent and non-independent directors do matter in a distressed company. 
Another question that arises is whether combining the roles of CEO and chairman, or CEO duality, leads to distress. Bursa Malaysia Listing Requirements (2001) made a recommendation that publiclisted companies separate the functions of CEO and chairman. This recommendation is important as many studies have found that CEO duality weakens the balance of powers at the top management (Fama \& Jensen, 1983), reduces the monitoring by the board of directors over the CEO and leads to worse performance (Dayton, 1984; White \& Ingrassia, 1992), which ultimately leads to a higher probability of distress. Hence, it is important to understand the relationship between CEO duality and financial distress.

Many companies are managed by their founders who also act as CEOs. There are studies that show companies which are led by founderCEOs would have lower performance than those led by non-founderCEOs. This happens because large and complex business corporations would require a specific type of managerial skill and that may not be readily available for founder-CEOs (Willard, Krueger, \& Feeser, 1992) and also because of the mismatch in managerial competence and the requirements of a changing environment (Daily \& Dalton, 1993; Jayaraman et al., 2000). Hence, it is important to study whether CEO-founder is a factor that leads to distress.

Recognizing the importance of these factors to maintain the sustainability of companies, the objective of the study was to examine how board characteristics (size of the board, percentage of independent directors, percentage of executive directors, percentage of non-independent non-executive directors, CEO duality, CEOfounder) are related to the probability of companies' experiencing distress.

This study has policy implications related to corporate governance. MCCG comes up with a list of good governance practices. It is expected that companies which adopt the practices will have lower probability of being in financial distress. Thus, this study could be used to measure the effectiveness of MCCG especially on the percentages of independent directors serving on the board. This study is also useful to directors and investors. From this study, the directors can identify factors that explain distress and evaluate the existence of these factors in their companies. Investors can use this study to predict corporate 
distress and stay away from investing in firms that are more likely to experience distress.

Finally, this study uses an approach different from previous studies where this study defines distress similar to one of the criteria used in PN17 where distress is identified as when the shareholders' fund to issued and paid-up capital of a firm is less than $25 \%$. Furthermore, this study uses a sample from 2004 to 2009. Most of the previous studies used the sample based on the Asian Financial Crisis (AFC) of 1997. Thus, this study uses the sample after AFC but still reflects the global financial crisis of 2008 .

The study is limited to examining the effect of corporate governance in predicting financial distress for a period of six years (from 2004 to 2009). It only focuses on examining the effect of board structures on the probability of distress.

\section{Review of Literature}

\section{Independent director}

Daily and Dalton (1994) and Hambrick and d'Aveni (1998) found evidence that the number of independent directors is related to financial distress. In essence, Daily and Dalton (1994) found that the percentage of insider directors on the board of directors (BOD) is higher and the proportions of independent directors and bankruptcy are negatively and significantly related. In addition, Hambrick and d'Aveni (1998) found that there is a decrease in the number of outside directors in the years preceding a bankruptcy filing. Judge and Zeithaml (1992) argue that a higher proportion of insiders on a board would lead to a lack of involvement in strategic decisionmaking which will jeopardize the company's future. Eloumi and Gueyie (2001) support the view that independent outside directors are a key factor in enhancing a firm's financial conditions as they are more willing to use their powers to monitor and discipline the managers. Li, Wang and Deng (2008) found that listed Chinese firms that have a higher proportion of independent directors would less likely experience financial distress as compared to those firms with a lower proportion of independent directors. These results support the monitoring role of independent directors. 
Hermalin and Weisbach (1988) find that poorly performing firms tend to remove insiders and add outsiders to run their company. According to them, a greater proportion of outside directors tends to take actions in line with shareholders' interest and can make better acquisition-related activities. Using mean comparison, Platt and Platt (2012) showed that the number of independent directors on boards is positively related to the company's financial health. Parker et al. (2002) found that a financially distressed firm that replaced its CEO with an outsider is more likely to experience bankruptcy.

On the other hand, Chaganti, Mahajan and Sharma (1985) found no significant relationship between corporate failure and the proportion of outsiders and insiders. Robinson et al. (2012) also found that there is no evidence that the proportion of outside directors is significantly associated with the likelihood that a Chapter 11 firm liquidates, when they analyzed 152 bankruptcy filings of publicly traded US firms from 1994 to 2004 using probit regression models. Given the mixed relationship between outside directors and financial distress, we hypothesize that there is a relationship between independent directors and financial distress and there is a relationship between non-independent non-executive directors and financial distress.

Executive directors play a vital role in ensuring business performance. The inclusion of executive (inside) directors on the BOD poses contradictory issues. On the one hand, their inclusion is important and may lead to more effective decision-making processes (Fama and Jensen, 1983). Executive directors can effectively assist the CEO to maximise the company's value by providing advice and knowledge about the day-to-day operations. On the other hand, their inclusion invites skepticism as to whether they can be independent enough to judge managerial performance. It is hypothesized that there is a relationship between the proportion of executive directors on the board and the likelihood of distress.

\section{CEO Duality}

The Cadbury Committee published a code of best practice which recommended the separation of functions between the Chairman and the CEO. The separation is seen as important since the CEO is responsible for the daily operations while the Chairman is responsible for monitoring and evaluating the performance of the executive 
directors and the CEO (Laing \& Weir, 1999). Rechner and Dalton (1991) support the idea, stating that combined roles frequently lead to a decline in performance while Daily and Dalton (1993) state that combining the roles is a sign of strong CEO power, which may lead to poor performance. Moreover, Rechner and Dalton (1991) argue that firms that separate the two positions are better facilitated to undertake more effective monitoring and control of the CEO than firms that combine the two positions.

According to the agency theory, CEO duality reduced firm performance as it compromises the monitoring and control of the CEO (Dayton, 1984) which weakens the balance of powers at the top management (Fama \& Jensen, 1983). When the two top management posts are held by the same person, there is a tendency that the board cannot remove an underperforming CEO (White \& Ingrassia, 1992) and this action creates an agency cost if the CEO pursues his own interest at the cost of the shareholders. As for the distressed companies, Daily and Dalton (1994) and Darrat et al. (2010) find that CEO duality is positively related to bankruptcy.

However, Alexander, Fennell and Halpern (1993) argue that when a single person plays the role of both the Chairman and CEO, it improves firm value as the agency cost between the two is eliminated. Under the stewardship theory, CEO duality is good for performance as it provides unity of command. Donaldson and Davis (1991) argue that CEO duality presents a strong and an unambiguous leadership with a unity of command and indicates that firms with CEO duality make better and faster decisions as compared to those without CEO duality. Finkelstein and D'Aveni (1994) argue that CEO duality helps to avoid confusion between managers, employees and other stakeholders because CEO-chairman is the leader who facilitates more timely and more effective decision-making. Abdul Rahman and Haniffa (2005) argue that the role of CEO duality helps in decision-making as it permits a sharper focus on company objectives and promotes more rapid implementation of operational decisions, hence reducing the probability of distress. Duality also helps the CEO in understanding strategic vision to shape the destiny of the company with minimum board interference (Dahya, Lonie \& Power, 1996). However, Chaganti et al. (1985) find that CEO duality does not have any effect on the probability of financial distress. Based on these arguments, our hypothesis is as follows: there is a relationship between CEO duality and financial distress. 
IJMS 25 (1), 41-60 (2018)

\section{Founder CEO}

The presence of a founder in the top management indicates stronger insider commitment and it implies a continuation or extension of the existing strategy. Founder CEO also helps to prevent risks and costs associated with any radical strategic swifts due to leadership change; hence, it provides a valuable signal to outside investors about the firm's current and potential value.

Earlier research on the effects of founder-CEOs on operating performances and market valuations has produced mixed findings. Morck et al. (1988) found that for older firms, there is a negative effect of founding family control on market valuations. For the younger firms in their sample, the market value effect of having a member of the founding family as one of the top two executives is positive. Perez-Gonzalez (2006) found that inherited control by a family member is associated with a decline in firm performance. In contrast, Sraer and Thesmar (2007) found that family control is positively related to performance, and Villalonga and Amit (2006) found a positive relation between founder-CEOs and firm performance. Based on the literature, our next hypothesis is that: there is a relationship between CEO-founder and financial distress.

\section{Board size}

According to the agency theory, larger boards provide effective monitoring by reducing the domination of the CEO and hence, improve the performance (Fama and Jensen, 1983; Zahra \& Pearce, 1989). The need of CEOs need for advice increases with the complexity of the firm (Anderson et al., 2004). A larger board size indicates the role of monitoring and advisory (Anderson, Mansi, \& Reeb, 2004) and it provides valuable resources to the firm (Hillman et al., 2000). A larger board size is also related to a firm's ability to access critical resources and the external environment (Hillman et al., 2000; Hillman \& Dalziel, 2003). Moreover, companies with larger board size are less likely to fail (Chaganti et al., 1985; Platt \& Platt, 2012).

On the other hand, Kiel and Nicholson (2003) and Lipton and Lorsch (1992) found that a small board tends to be more effective because it is easier to coordinate. Since a small board has greater coordination, they are able to make efficient decision-making resulting from better communication (Jensen, 1993). As a result, a smaller board will exhibit 
higher performance (Eisenberg, Sundgren \& Wells, 1998). Lipton and Lorsch (1992) argue that a larger board normally has problems of social loafing and free riding. However, for bankrupt companies, Darrat et al. (2010) find that they are more likely to have small boards of directors compared to their solvent counterparts.

In Malaysia, Gani and Jermias (2006) found that performance is positively and significantly related to board size, which indicates that a larger board is associated with better decision-making and monitoring of managers and consequently leads to an increase in firm performance. This result might indicate that larger board size increases the independence of the board and reduces the problem of managerial entrenchment (Zahra \& Pearce, 1989).

Yermack (1996) and Ibrahim and Samad (2008) found that performance is negatively and significantly related to board size. This result indicates that it is easier to monitor managers with a small board and a small board leads to better decision-making. Hence, the mixed findings lead us to the next hypothesis which is: there is a relationship between board size and financial distress.

\section{Control variables}

Since the likelihood of distress is influenced by economic circumstances, for example, distress is more likely during a recession, economic indicators are used to control for economic influence. Similar to previous studies (see for example, Shumway, 2001), this study used market return, lagged of market return, and GDP growth to represent economic indicators. These factors needed to be included in the model to ensure the results are robust. Market return, lagged of market return and GDP growth are expected to affect distress negatively as during good times, firms have better investment opportunities and could pay-off their debts.

Financial leverage will lead to financial distress as a firm relies on debt more than equity. This is consistent with the results of the studies by Ting (2011) where debt level has a negative and significant impact on performance and where firms with higher debt would have a higher probability of default. Debt ratio which is calculated by dividing total debt by total assets provides information on a company's insolvency and its ability to secure additional financing for good investment 
opportunities. This is to ensure that creditors are protected. Ohlson (1980) and Mohamed et al. (2001) found that this ratio is a significant determinants of corporate failure. Another control variable used is profitability which is measured by net income to total assets. Altman (1968) find that profitable companies are less likely to experience distress.

\section{Methodology}

The sample included all firms listed on the Main Market of Bursa Malaysia. There are two different measures of distress that are used by Bursa Malaysia. One is based on a criterion which was being used in Practice Notes 17 (PN17) and is defined as the shareholders' equity less than $25 \%$ of the issued and paid-up capital of a firm. The other measure used by Bursa Malaysia before the introduction of PN17 is based on a criterion used in Practice Notes 4 (PN4) and that criterion is negative shareholders' equity. Using the criterion of PN17 would lead to more firms being identified as distressed since PN4 firms is a subset of PN17 firms as firms, with negative shareholders' equity would have less than $25 \%$ of issued and paid-up capital. This study used the criterion in PN17.

The sample period of this study was from 2004 to 2009. A firm had to meet the distress criterion during this period to be identified as a distressed firm. A total of 589 observations for distressed firms and 589 observations for non-distressed firms were used as the sample. The firms were match-based on size as measured by total assets and industrial classification, as categorized by Bursa Malaysia. Matching was done at the end of 2004.

To investigate whether governance characteristics influence the occurrence of distress, a multiperiod logistic regression model of the following form was estimated:

$$
\mathrm{P}_{\mathrm{i}}=\frac{1}{1+e^{-z_{i}}}
$$

where $\mathrm{Z}$ is the linear combination

$$
Z_{\text {it }}=\alpha_{0}+\beta_{1} X_{1 i t}+\beta_{2} X_{2 i t}+\beta_{3} X_{3 i t}+\ldots \ldots \ldots+\beta_{n} X_{\text {nit }}
$$


It can also be written as follows:

$\mathrm{Z}_{\mathrm{it}}=\alpha_{0}+\beta_{1} \mathrm{LNBSIZE}_{\mathrm{it}}+\beta_{2}$ FINED $_{\mathrm{it}}+\beta_{3}$ FNINED $_{\mathrm{it}}+\beta_{4}$ FEXECDIR $_{\mathrm{it}}+$ $\beta_{5}$ D 4 CEOCHAIR $+\beta_{6}$ CEOFOUND $+\beta_{7}$ LAGMKTRET $_{\text {it }}+\beta_{8}$ D 4 MKTRET it $+\beta_{9}$ GDP $_{\mathrm{t}}+\beta_{10}$ LEVERAGE $_{\mathrm{it}}+\beta_{11} \mathrm{NI}_{2} \mathrm{TA}_{\mathrm{it}}+\varepsilon_{\mathrm{t}}$

Where $i$ refers to firm, $t$ refers to time, and

$P_{i}$

LNBSIZE

FINED

FNINED

FEXECDIR : Proportion of executive directors to total directors

D4CEOCHAIR : A binary variable that equals to 1 if the CEO is also the chairman

CEOFOUND : A binary variable that equals to 1 if the CEO is also the founder

LAGMKTRET : The lagged market return

D4MKTRET : The market return

GDP : Gross domestic products

LEVERAGE : Total debt to total assets

NI2TA : Net income to total assets

\section{Results and Discussion}

\section{Descriptive statistics}

Table 1 summarizes the statistics of the relevant variables for the two groups of distressed and matching firms if distress is identified by using a cut-off point of $25 \%$. Board size, as measured by the natural logarithm of the number of directors (LNBSIZE), is smaller for distressed firms compared to that of matching firms and it is significant based on either the parametric difference-of-two-means test or the non-parametric Mann-Whitney U-test. As a company enters 
into financial problems, it will cut costs. One way of doing this is by reducing employees including directors. Furthermore, a company in financial distress may want to expedite its decision-making process. A smaller board allows that to happen. A breakdown of the board size into three categories of independent directors (INED), nonexecutive non-independent directors (NINED) and executive directors (EXECDIR) shows that the number of independent directors does not change as the p-values for both tests are not significant. However, the number of non-executive non-independent directors and executive directors are lower for distressed firms. When ratios of independent (FINED), non-executive non-independent (FNINED) and executive (FEXECDIR) are used, it is found that FINED is greater in distressed firms. This result suggests that independent directors could give a more objective assessment of a distressed firm's conditions and they could be relied upon to resolve the financial problems of the firm. This suggestion is strengthened by the fact that the ratio of executive directors in a distressed firm is lower compared to that of a matching firm.

CEO-chairman duality (D4CEO-CHAIR) is significantly higher in distressed firms $(22.24 \%)$ as compared to that in matching firms (17.73\%). As distressed firms must be more agile in decision-making, uniting the two functions (CEO and chairman) would lead to speedier actions. On the other hand, it could also be argued that by having duality the CEO would become more powerful and more autocratic. This might lead to problems.

Table 1

Summary Statistics for and Differences between Distressed and Matching Firms

\begin{tabular}{lcccc}
\hline Variables & $\begin{array}{c}\text { Distressed } \\
\text { firms }\end{array}$ & $\begin{array}{c}\text { Matching } \\
\text { firms }\end{array}$ & $\begin{array}{c}\text { p-value for } \\
\text { difference- } \\
\text { in-means } \\
\text { test }\end{array}$ & $\begin{array}{c}\text { p-value } \\
\text { for Mann- } \\
\text { Whitney } \\
\text { U-test }\end{array}$ \\
\hline LNBSIZE & 1.84795 & 1.99044 & 0.000 & 0.000 \\
INED & 3.04075 & 3.12909 & 0.153 & 0.115 \\
NINED & 1.23430 & 1.43029 & 0.012 & 0.011 \\
EXECDIR & 2.33107 & 2.98279 & 0.000 & 0.000 \\
\hline & & & & (continued)
\end{tabular}


IJMS 25 (1), 41-60 (2018)

\begin{tabular}{lcccc}
\hline Variables & $\begin{array}{c}\text { Distressed } \\
\text { firms }\end{array}$ & $\begin{array}{c}\text { Matching } \\
\text { firms }\end{array}$ & $\begin{array}{c}\text { p-value for } \\
\text { difference- } \\
\text { in-means } \\
\text { test }\end{array}$ & $\begin{array}{c}\text { p-value } \\
\text { for Mann- } \\
\text { Whitney } \\
\text { U-test }\end{array}$ \\
\hline FINED & 0.47025 & 0.41854 & 0.000 & 0.000 \\
FNINED & 0.17850 & 0.18945 & 0.278 & 0.249 \\
FEXECDIR & 0.35206 & 0.39193 & 0.000 & 0.000 \\
D4CEO- & 0.22241 & 0.17728 & 0.054 & 0.054 \\
Chair & & & & \\
D4CEO- & 0.09338 & 0.20482 & 0.000 & 0.000 \\
Found & 0.06839 & 0.07100 & 0.851 & 0.984 \\
LagMktRet & 0.08255 & 0.08076 & 0.907 & 0.876 \\
MktRet & 0.04832 & 0.04861 & 0.849 & 0.984 \\
GDP & 0.71118 & 0.20865 & 0.000 & 0.000 \\
Leverage & -0.10111 & 0.03222 & 0.052 & 0.000 \\
NI2TA & & & & \\
\hline
\end{tabular}

CEO-founder (D4CEO-FOUND) is significantly lower in distressed firms $(9.34 \%)$ as compared to that in matching firms (20.48\%). It could be argued that a founder who served as CEO would significantly improve the performance of the firms as he is personally attached to the firm and considers the firm as his crowning achievement. Therefore, he would work hard to make sure that the firm survives and thrives. On the other hand, if a firm starts showing signs of distress, the founder might relinquish his post as CEO.

As for financial variables, it is found that the financial position of matching firms is significantly superior to those of distressed firms. Leverage (LEVERAGE) is higher for distressed firms while net income to total assets (NI2TA) is significantly lower for distressed firms.

\section{Correlation analysis}

Table 2 describes the correlation between the variables. Gujarati (2003) suggests that a correlation above 0.5 might lead to multicollinearity problems. All the correlations are less than 0.5 except those between those FNINED and FEXECDIR (-0.709), LAGMKTRET and MKTRET $(-0.567)$ and LAGMKTRET and GDP (0.902). In the subsequent regression analyses, these correlations were taken into consideration by dropping the highly correlated variables. 
IJMS 25 (1), 41-60 (2018)

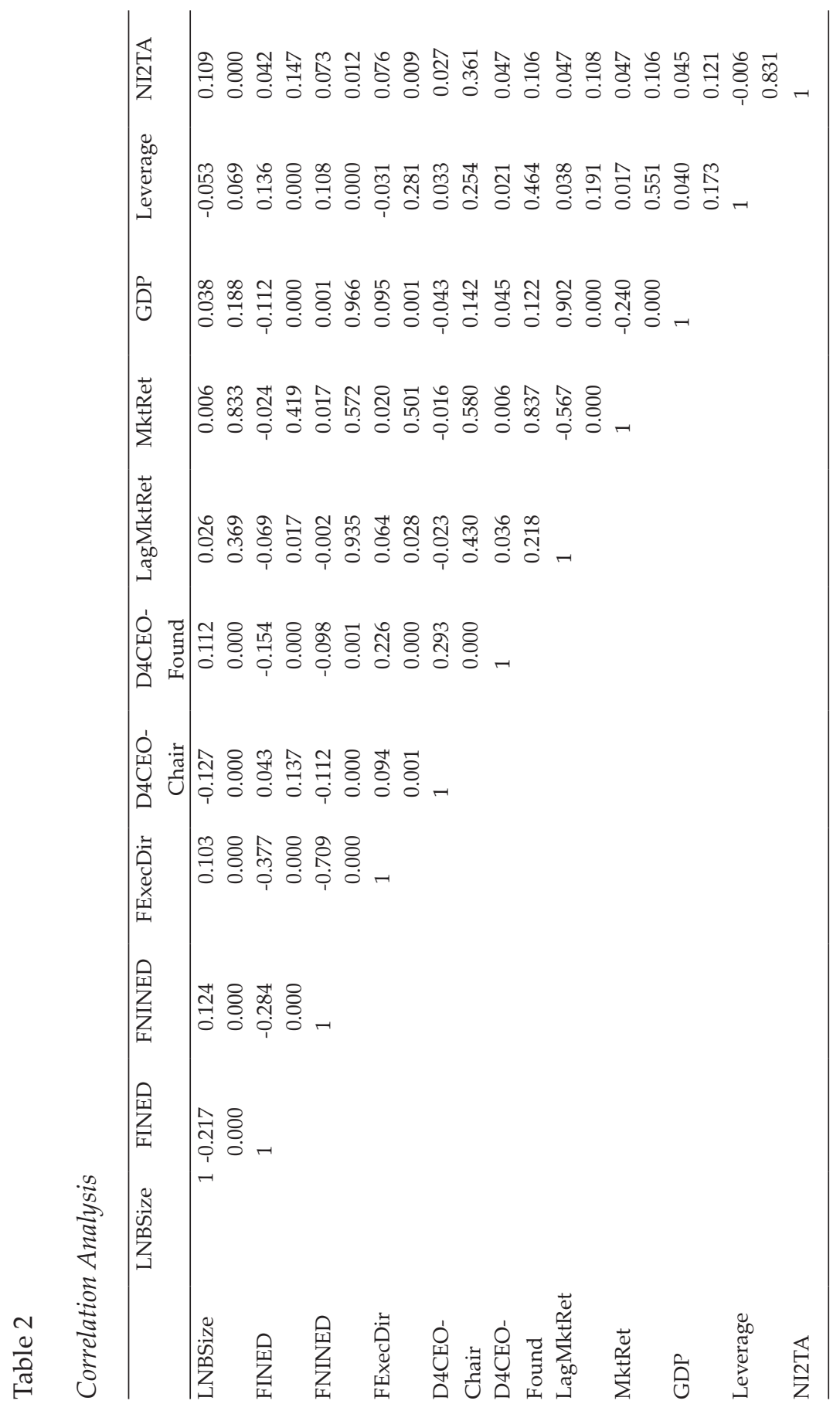




\section{Regression analysis}

Table 3 summarizes the results of the logit analysis. Model 1 summarizes the results of the governance variables. The results show that distressed firms have smaller boards (LNBSIZE). Smaller boards lead to faster decision-making, which is crucial to firms facing financial difficulties. Furthermore, expenses could be reduced by decreasing board members. The fraction of independent director (FINED) explains distress positively and the coefficient is significant at $5 \%$. To solve financial difficulty problems, distressed firms would tend to hire an outside party with a more objective view of the problem. In this case the firm would hire independent directors. In addition, distressed firms might terminate the employment of nonperforming top management including executive directors. Thus, the fraction of independent directors would go up.

D4CEOCHAIR is positively significant at $5 \%$. There are two opposing arguments on the effects of CEO duality on distress. One argument based on the agency theory is that it would increase the likelihood of distress as the same person has the ultimate power for decisionmaking in the company. Furthermore, it is going to be very difficult to remove the underperforming $\mathrm{CEO}$ as he also serves as the Chairman of the board. The other argument based on the stewardship theory states that CEO duality would expedite the decision-making process. The results of this study support the arguments of the agency theory which is in line with the recommendation of MCCG 2007. However, the positive sign might also indicate that as distressed firms have to speed up their decision-making processes, CEO duality is valuable to these firms, which is consistent with the stewardship theory.

D4CEOFOUND is negatively significant in explaining the likelihood of distress. The significant negative relationship between D4CEOFOUND and distress shows that since founders are personally attached to their firms they have greater incentives in ensuring the survival of the firms. Model 1 correctly classified distress and matching firms (67.89\%).

Model 2 extends the previous model by including control variables. When control variables are added, results of governance variables do not change except for D4CEOCHAIR where it is not significant 
IJMS 25 (1), 41-60 (2018)

any more. As for the market and economic variables (LAGMKTRET, MKTRET, and GDP), they are not significant. LEVERAGE has the expected positive sign while NI2TA has an unexpected positive sign.

Table 3

Regression Results for all Models

\begin{tabular}{|c|c|c|}
\hline & MODEL 1 & MODEL 2 \\
\hline d4distress & $\begin{array}{c}\text { Coef. } \\
\text { (P-value) }\end{array}$ & $\begin{array}{c}\text { Coef. } \\
\text { (P-value) }\end{array}$ \\
\hline LNBSIZE & $\begin{array}{l}-1.713 \\
(0.000)\end{array}$ & $\begin{array}{l}-1.467 \\
(0.000)\end{array}$ \\
\hline FINED & $\begin{array}{l}3.328 \\
(0.040)\end{array}$ & $\begin{array}{c}4.071 \\
(0.060)\end{array}$ \\
\hline FNINED & $\begin{array}{c}1.263 \\
(0.415)\end{array}$ & $\begin{array}{c}2.472 \\
(0.233)\end{array}$ \\
\hline FEXECDIR & $\begin{array}{c}2.311 \\
(0.144)\end{array}$ & $\begin{array}{c}3.298 \\
(0.117)\end{array}$ \\
\hline D4CEOCHAIR & $\begin{array}{c}0.385 \\
(0.029)\end{array}$ & $\begin{array}{c}0.185 \\
(0.293)\end{array}$ \\
\hline D4CEOFOUND & $\begin{array}{l}-0.569 \\
(0.006)\end{array}$ & $\begin{array}{l}-0.686 \\
(0.001)\end{array}$ \\
\hline LAGMKTRET & & $\begin{array}{c}0.900 \\
(0.502)\end{array}$ \\
\hline MKTRET & & $\begin{array}{c}0.274 \\
(0.610)\end{array}$ \\
\hline GDP & & $\begin{array}{l}-9.592 \\
(0.366)\end{array}$ \\
\hline LEVERAGE & & $\begin{array}{c}4.264 \\
(0.000)\end{array}$ \\
\hline NI2TA & & $\begin{array}{c}0.141 \\
(0.009)\end{array}$ \\
\hline Constant & $\begin{array}{c}1.328 \\
(0.428)\end{array}$ & $\begin{array}{l}-1.312 \\
(0.562)\end{array}$ \\
\hline P-value) & $\begin{array}{l}174.63 \\
(0.000)\end{array}$ & $\begin{array}{l}294.05 \\
(0.000)\end{array}$ \\
\hline Pseudo- $R^{2}$ & 0.133 & 0.264 \\
\hline Percentage correctly predicted & 67.89 & 73.97 \\
\hline $\begin{array}{l}\text { Percentage distress correctly } \\
\text { predicted }\end{array}$ & 65.48 & 71.94 \\
\hline Percentage match correctly predicted & 70.34 & 76.03 \\
\hline
\end{tabular}




\section{Conclusion}

This study examined the influence of corporate governance attributes in predicting financial distress. Attributes that were included in this study were board size, proportions of different types of directors (independent, non-independent non-executive, and executive), CEO duality and CEO-founder while the control variables were market return, lag of market return, GDP, leverage and net income to total asset.

The sample selection process from 2004 to 2009 resulted in a total of 589 observations of distressed firms. An equal number of control firms was identified based on size and industry. This process resulted in 1170 firm-year observations. Both univariate tests and the multiperiod logistic regression models were applied to test whether the variables chosen explained the incidence of distress.

The results show that board size and CEO founder are negatively related to the probability of distress. The significant negative relationship between CEO founder and distress shows that since founders are personally attached to their firms they have greater incentives to ensure the survival of the firms. On the other hand, the fraction of independent directors and CEO duality explain distress positively. The study also shows that the market and economic variables do not play any role in explaining the probability of distress.

Since empirical research on the effects of corporate governance and financial distress is still limited in Malaysia, it could be explored further. One suggestion is to look at the effects of directors' education and qualification on distress. The role of audit committees could also be investigated as audit committees can foresee the financial condition of the company.

\section{References}

Abdullah, S. N. (2006). Board structure and ownership in Malaysia: The case of distressed listed companies, Corporate Governance, 6(5), 582-594.

Abdul Rahman, R., \& Haniffa, R. M. (2003). Effectiveness of internal governance mechanisms: An empirical analysis of Malaysian 
listed companies for the period 1996-2000, Proceeding of ANZAM Conference.

Alexander, J., Fennell, M., \& Halpern, M. (1993). Leadership instability in hospitals: The influence of board-CEO relations and organization growth and decline. Administrative Science Quarterly, 38, 74-99.

Altman, E. I. (1968). Financial ratios, discriminant analysis and the prediction of corporate bankruptcy, Journal of Finance, 23, 589609.

Anderson, R. C., Mansi, S. A., \& Reeb, D. M. (2004). Board characteristics, accounting report integrity, and cost of debt. Journal of Accounting and Economics, 37(3), 315-342.

Chaganti, R. S., Mahajan, V., \& Sharma, S. (1985). Corporate board size, composition and corporate failures in the retailing industry, Journal of Management Studies, 22, 400-417.

Daily, C. M., \& Dalton, D. R. (1993). Board of directors, leadership and structure: Control and performance implications. Entrepreneurship Theory and Practice, 17, 65-81.

Daily, C. M., \& Dalton, D. R. (1994). Bankruptcy and corporate governance: The impact of board composition and structure. Academy of Management Journal, 37, 1603-1617.

Daily, C.M., Dalton, D. R., \& Cannella, A. A. (2003). Corporate governance: Decades of dialogue and data. The Academy of Management Review, 28(3), 371-382

Dahya, J., Lonie, A. A., \& Power, D. M. (1996). The case for separating the roles of chairman and CEO: An analysis of stock market and accounting data. Corporate Governance: An International Review, 4, 71-77.

Darrat, A. F., Gray, S., \& Wu, Y. (2010). Does board composition affect the risk of bankruptcy? Retrieved from: http://ssrn.com/ abstract $=1710412$

Dayton, N. (1984). Corporate governance: The other side of the coin, Harvard Business Review, 62, 34-37.

Demsetz, H., \& Lehn, K. (1985). The structure of corporate ownership: Causes and consequences, Journal of Political Economy, 93, 11551177.

Donaldson, L., \& Davis, J. (1991) Stewardship theory or agency theory: CEO governance and shareholder returns. Australian Journal of Management, 16, 49-64.

Eisenberg, T., Sundgren, S., \& Wells, M. (1998). Larger board size and decreasing firm value in small firms. Journal of Financial Economics, 48, 35-54. 
Eloumi, F., \& Gueyie, J. P. (2001). Financial distress and corporate governance: An empirical analysis. Corporate Governance, 1, 1523.

Fama, E. F., \& Jensen, M. C. (1983). Separation of ownership and control. Journal of Law and Economics, 26, 301-325.

Finkelstein, S., \& D'Aveni, R. (1994). CEO duality as a doubleedged sword: How boards of directors balance entrenchment avoidance and unity of command, Academy of Management Journal, 37, 1079-1108.

Gani, L., \& Jermias, J. (2006). Investigating the effect of board independence on performance across different strategies. The International Journal of Accounting, 4, 295-314

Hambrick, D. C., \& D'Aveni, R. A. (1988). Large corporation failures as downward spirals. Administrative Science Quarterly, 33, 1-23.

Hermalin, B., \& Weishbach, M. (1988). The determinants of board composition. Rand Journal of Economics, 19(4), 589-606.

Hillman, A. J., \& Dalziel, T. (2003). Boards of directors and firm performance: Integrating agency and resource dependency perspectives. Academy of Management Review, 28(3), 383-396.

Hillman, A, Cannella, A., \& Paetzold, R. (2000). The resource dependence role of corporate directors: Strategic adaptation of board composition in response to environmental change. Journal of Management Studies, 37, 213-255.

Ibrahim, H., \& Samad, F. A. (2008). Agency costs, corporate governance mechanisms and performance of public listed family firms in Malaysia (Unpublished doctoral thesis). University of Malaya.

Jayaraman, N., Khorana, A., Nelling, E., \& Covin, J. (2000). CEO founder status and firm financial performance. Strategic Management Journal, 21(12), 1215-1224.

Jensen, M. C. (1993). The modern industrial revolution, exit, and the failure of the internal control systems. Journal of Finance, 48(3), 831-880.

Judge, W. Q., \& Zeithaml, C. P. (1992). Institutional and strategic choice perspectives on board involvement in the strategic decision process. Academy of Management Journal, 766-794.

Kets, de Vries, M. F. R. (1993). The dynamics of family controlled firm: The good and the bad news. Organizational Dynamics, 21(3), 59-71.

Kiel, G. C., \& Nicholson, G. J. (2003) Board composition and corporate performance: How the Australian experience informs contrasting theories of corporate governance. Corporate Governance: An International Review, 11(3), 189-205. 
Laing, D., \& Weir, C.M. (1999) Governance structures, size and corporate performance in UK firms. Management Decision, 37(5), 457-64.

Li, H., Wang, \& Deng, X. (2008). Ownership, independent directors, agency costs and financial distress: Evidence from Chinese listed companies. Corporate Governance, 8(5), 622-636.

Lipton, M., \& Lorsch, J. W. (1992). A modest proposal for improved corporate governance. Business Lawyer, 1(1), 59-77.

Malaysian Code of Corporate Governance (MCCG). (2001). Malaysian Institute of Corporate Governance (MCCG). Malayan Law Journal Sdn. Bhd: Kuala Lumpur.

Md-Rus, R., Taufil Mohd, K. N., \& Abdul Latif, R. (2013). Ownership structure and financial distress. Journal of Advanced Management Science, 1(4), 363-367.

Mohamed, S., Li, A. J., \& Sanda, A. U. (2001). Predicting corporate failure in Malaysia: An application of the Logit Model to financial ratio analysis. Asian Academy of Management Journal, 6(1), 99-118.

Morck, R. K., Shleifer, V., \& Vishny, R. W. (1988). Management ownership and market valuation: An empirical analysis. Journal of Financial Economics, 20, 293-315.

Ohlson, J. A. (1980). Financial ratios and the probabilistic prediction of bankruptcy. Journal of Accounting Research, 18, 109-131.

Parker, S., Peters, G. F., \& Turetsky, H. F. (2002) Corporate governance and corporate failure: A survival analysis. Corporate Governance, 2, 4-12.

Perez-Gonzalez, F. (2006). Inherited control and firm performance, American Economic Review, 96, 1559-1588.

Platt, H., \& Platt, M. (2012). Corporate board attributes and bankruptcy. Journal of Business Research, 65, 1139-1143.

Rechner, P. L., \& Dalton, D. R. (1991). CEO duality and organizational performance: A longitudinal analysis. Strategic Management Journal, 12, 155-160.

Robinson, D., Robinson, M., \& Sisneros, C. (2012). Bankruptcy outcomes: Does the board matter? Advances in Accounting incorporating Advances in International Accounting, 28, 270,278.

Shumway, T. (2001). Forecasting bankruptcy more accurately: A simple hazard model. Journal of Business, 74(1), 101-124.

Sraer, D., \& Thesmar, D. (2007). Performance and behavior of family firms: Evidence from the French stock market. Journal of the European Economic Association, 5(4), 709-751. 
IJMS 25 (1), 41-60 (2018)

Ting, W. (2011).Top management turnover and firm default risk: Evidence from the Chinese securities market. China Journal of Accounting Research, 4(1-2), 81-89.

Villalonga, B., \& Amit, R. (2006). How do family ownership, control and management affect firm value? Journal of Financial Economics, 80, 385-417.

Weisbach, M. S. (1988). Outside directors and CEO turnover. Journal of Financial Economics, 20, 431-460.

White, J., \& Ingrassia, P. (1992) Board ousts managers at GM: Takes control of crucial committee. The Wall Street Journal, 7, 1-8.

Willard, G. E., Krueger, D. A., \& Feeser, H. R. (1992). In order to grow, must the founder go: A comparison of performance between founder and non-founder managed high-growth manufacturing firms. Journal of Business Venturing, 7(3), 181194.

Wruck, K.H. (1990). Financial distress, reorganization, and organizational efficiency. Journal of Financial Economics, 27, 419-44.

Yermack, D. (1996). Higher market valuation of companies with a small board of directors. Journal of Financial Economics, 40, 185211.

Zahra, S., \& Pearce, J. (1989). Boards of directors and corporate financial performance: A review and integrative model. Journal of Management, 15(2), 291-3. 